\author{
Abstracta Iranica \\ Abstracta Iranica Revue bibliographique pour le domaine irano-aryen \\ Volume 40-41 | 2019 \\ Comptes rendus des publications de 2017-2018
}

\title{
Kevin Van Bladel. From Sasanian Mandaeans to Șäbians of the Marshes
}

\section{Florence Somer}

\section{(2) OpenEdition}

Édition électronique

URL : http://journals.openedition.org/abstractairanica/50978

DOI : 10.4000/abstractairanica.50978

ISBN : 1961-960X

ISSN : 1961-960X

Éditeur :

CNRS (UMR 7528 Mondes iraniens et indiens), Éditions de l'IFRI

Référence électronique

Florence Somer, "Kevin Van Bladel. From Sasanian Mandaeans to Sābians of the Marshes », Abstracta Iranica [En ligne], Volume 40-41 | 2019, document 25, mis en ligne le 30 décembre 2019, consulté le 17 avril 2021. URL : http://journals.openedition.org/abstractairanica/50978 ; DOI : https://doi.org/ 10.4000/abstractairanica.50978

Ce document a été généré automatiquement le 17 avril 2021

Tous droits réservés 
Kevin Van Bladel. From Sasanian Mandaeans to Șäbians of the Marshes

Florence Somer 


\section{RÉFÉRENCE}

Kevin Van Bladel. From Sasanian Mandaeans to Șābians of the Marshes. Leiden: Brill, 2017, 153 p. (Leiden Studies in Islam and Society 6)

Ce volume résume des années d'études consacrées initialement aux Sabéens décrits dans le Coran, auxquels les Mandéens sont associés. Les premiers chapitres remontent aux origines de ce groupe religieux baptiste dans l'Irak sassanide et met en lumière des témoignages qui montrent leur présence en Mésopotamie durant le 5e s., bien avant l'apparition de l'Islam, où ils se font appeler Nasoréens en se construisant une identité inspirée par les traditions juives chrétiennes ou zoroastriennes. L'A. reconsidère la datation d'un livre de prières mandéen dit du 3e s. de notre ère pour le situer au 7e s. au moment de la conquête musulmane. Alors que les sources arabes ne mentionnent pas l'existence des Mandéens avant la période abbasside, les sources syriaques chrétiennes condamnent bien plus tôt l'existence de cette secte qu'ils qualifient d'hérétique. Théodore Bar Konay les mentionne dans son Livre des Scholies et établi son origine au $5 \mathrm{e}$ s. de notre ère sous le règne de Pērōz où ils sont connus sous le nom de «Kentaya » et trois autres sources syriaques font références aux Mandéen au 6e s. La source pré-moderne la plus importante est signée par un mystérieux Abū 'Alī que l'A. identifie comme le vizir Ibn Muqla (m. 940) qui localise les Sabéens dans différents sites, tous construits autour d'un affluent du Tigre dans le sud irakien où ils sont restés relativement méconnus du pouvoir en place jusqu'alors. Ibn Muqla fait la description de ces Sabéens dans le but de discréditer et persécuter le groupe des Sabéens de Harran de Bagdad. l'A. revient ensuite sur les origines des Mandéens qu'il fait également remonter au $5 \mathrm{e}$ s. et postule qu'ils ont standardisé une écriture cursive araméenne issue du sud de la Mésopotamie.

\section{AUTEURS}

\section{FLORENCE SOMER}

Doctorante EPHE, Mondes iranien et indien, Paris 